\title{
KIDNEY FUNCTION
}

\section{9}

DEGRADATION OF ENDOTHELIAL SURFACE GLYCOSAMINOGLYCANS AND FIBRONECTIN FOLLOWING TREATMENT WITH ENDOTOXIN AND NEUTROPHIS Klein N J, Finn A, Heyderman R S, Levin M. Paediatric Infectious Disease Unit, Department of paediatrics, St Mary's Hospital Medical School, London, United Kingdom.

Vascular endothelial damage is a major component of the physiological derangement seen in septicacmia. The sulphated glycosaminoglycans (GAGS) are thought to be involved in regulating endothelial permeability, thromboresistance and leucocyte traffic across the blood vessel wall. Modulation of CAG metabolism may therefore be important in causing the capillary leak and disseminated intravascular thrombosis often seen in bacterial sepsis.

We have previously shown that the cytokines IL1 and TNF modulate glycosaminoglycan We have previously shown that the cytokines and dermatan sulphate from the cell surface of cultured human umbilical vein endothelial cell cultures (HUVEC).

In the present study we have investigated the correlation between neutrophil activation and endothelial cell damage. 'To perform these experiments we have developed an endothelial model of surface injury using a cytochemical technique to visualise both endothelial GAGS and cellular fibronectin.

Results: We have demonstrated that the release of neutrophil proteases and neutrophil heparatinase are determined by the degree of both neutrophil and endothelial activation. When unstimulated neutrophils were added to HUVEC prestimulated with endotoxin, GAGS alone were degraded from the endothelial cell surface. However, when the formyl tripeptide fMLP, was included in the incubation, we also observed extensive destruction of the protease sensitive fibronectin network. When endotoxin and $\mathrm{MLP}$ were added simultaneously with the neutrophils there was minimal endothelial damage.

Conclusion: These results indicate that both neutrophil and endothelial activation is necessary to cause the breakdown of endothelial CACS and fibronectin. These results may be important in understanding the mechanisms of neutrophil induced endothelial damage in inflammation.

\section{0}

ENZYMATIC CHANGES IN THE CSF IN CHILDREN WITH NEUROINFECTIONS. Irja Lutsar, Milvi Topmann, Sulev Haldre, Tiina Talvi

Damage within the central nervous system(CNS) causes a leakage of intracellular enzymes into the cerebrospinal luid (CSF)

The CSF consentrations of lactic dehydrogenase (LDH), creatine phosphokinase (CPK), creatine kinase BB (CK-BB) and aspartataminotransferase (AST) were measured in children with viral meningoencephalitis-group(Gr): A, with bacterial meningitis (divided poor prognosis-Gr:B and good prognosis Gr:C) and with meningismus (Gr:D) on admission and after treatment to establish whether any of tho enzymes would correlate with

The activity of LDH, CPK and AST was determined by photocolourimetric assay (Labsystem) and CK-BB by
Results: Determination of enzymes on admission. Results: Determinat) CPK(U/I) LDH(U/I) AST(U/1)

$A(n=15) \quad 32.8 \pm 15.7 * 6.6 .1 \pm 5.2 \quad 29.3 \pm 23.2 * 4.2 \pm 2.4 *$

B $(n=8) \quad 19.5 \pm 23.4 \quad 6.1 \pm 7.3 \quad 120.1 \pm 109.8 * 21.2 \pm 23.5 *$

C $(n=18) \quad 49.0 \pm 16.6 \quad 4.8 \pm 2.7 \quad 47.1 \pm 63.8 \quad 8.1 \pm 2.9$

*p<0.005 (with respect to patients without meningitis)

**p<0.001 (with respect to good prognosis)

During the treatment the activity of $\mathrm{CPK}$ increased from ased from 6.1 to 2 Conclusion: A significant rise of LDH and AST activity, low amount of $\mathrm{CK}-\mathrm{BB}$ and decrease of $\mathrm{CPK}$ activity in the in children the treatment correlat

\section{1}

PHARMACOKINETICS OF VANCOMYCIN (V) IN TERM AND PRETERM NEONATES, A.Pecar, W.Lindner, V.Mönch, G.Münch, R.Roos.

Dept of Pediatrics, Dept of Pharmacy, University of Munich, Germany.

We examined half time ( $\mathrm{Pt} 1 / 2)$ and distribution volume (Vd) of $V$ in 22 (16

Wreterm and 6 term) critically ill neonates. $V$ was dosed: $20 \mathrm{mg} / \mathrm{kg} / \mathrm{d}$ OD

preterm and $6800 \mathrm{~g}), 30 \mathrm{mg} / \mathrm{kg} / \mathrm{d}$ OD $(800-1200 \mathrm{~g}), 40 \mathrm{mg} / \mathrm{kg} / \mathrm{d}$ TID $(>1200 \mathrm{~g})$, as $60 \mathrm{~min}$

$(<800 \mathrm{~g}), 30 \mathrm{mg} / \mathrm{kg} / \mathrm{d}$ OD $(800-1200 \mathrm{~g}), 40 \mathrm{mg} / \mathrm{kg} / \mathrm{d}$ TID $(>1200 \mathrm{~g})$, as $60 \mathrm{~min}$
infusion. Target concentrations were $20-40 \mathrm{mcg} / \mathrm{ml}(\mathrm{pk})$ and $<10 \mathrm{mcg} / \mathrm{ml}(\mathrm{tr})$.

infusion. Target concentrations were $20-40 \mathrm{mcg} / \mathrm{ml}(\mathrm{pk})$ and $<10 \mathrm{mcg} / \mathrm{ml}(\mathrm{tr})$.

88 drug levels were drawn: peak (pk) level 60 min after end of infusion, trough
(tr) level prior to the next dose. V concentrations were measured by fluorescence polarisation immunoassay (TDX Abbott). Data are $m \pm s D$ :

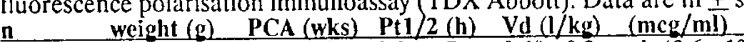

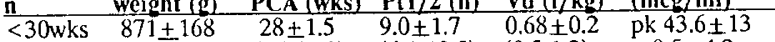

\begin{tabular}{llllll}
$n=20$ & $(640-1230)$ & $(25,5-29)$ & $(6,4-10.5)$ & $(0,5-1,2)$ & tr $9.5 \pm 4.2$ \\
\hline $30-37 w k s$ & $1431+255$ & $32+1.8$ & $7.7+4.3$ & $0.71+0.3$ & pk $36.8+8.7$
\end{tabular}

$\begin{array}{ll}7.7 \pm 4.3 & 0.71 \pm 0.3 \text { pk } 36.8 \pm 8.7\end{array}$

\begin{tabular}{llllll}
$n=32$ & $(1040-1950)$ & $(30-36)$ & $(3.1-17.2)$ & $(0.5-1.5)$ & tr $8.3 \pm 4.2$ \\
\hline$>37 w k s$ & $3196 \pm 1126$ & $45+5.7$ & $6.4 \pm 3.8$ & $0.83 \pm 0.2$ & pk $29.7 \pm 12.8$
\end{tabular}

$\begin{array}{lllll}37 \text { Wks } 3196 \pm 1126 & 45 \pm 5.7 & 6.4 \pm 3.8 & 0.83 \pm 0.2 & \text { pk } 29.7 \pm 12.8\end{array}$

$\frac{n=36}{\text { Results: Pt } 1 / 2 \text { is decreasing with PCA, but Vd is not related to PCA in our po- }}$

pulation. $36 \%(16 / 44)$ of pk levels were not within the therapeutic range: 2

below, 14 above the range. $30 \%(13 / 44)$ of tr levels were above the therapeutic range. In $64 \%(28 / 44)$ the dosing schedule was changed according to pharm cokinetic data: increased dose (7), decreased dose (15), lengthened interval

(12), shortened interval (3). The adjusted average dosage in our population was: for PCA < 30 wks: $17 \mathrm{mg} / \mathrm{kg}$ every $25 \mathrm{~h}$; PCA $30-37 \mathrm{wks}: 17 \mathrm{mg} / \mathrm{kg}$ every $20 \mathrm{~h}$; PCA > 37 wks: $18 \mathrm{mg} / \mathrm{kg}$ every $19 \mathrm{~h}$. Conclusion: Therapeutic drug monitoring of $\mathrm{V}$ is essential because of high interpatient variability, to avoid toxicity and to ensure therapeutic blood levels. We suggest a revision of current dosing recommendations in preterm neonates.

\section{2}

A POSTNATAL INCREASE IN CONTACT INHIBITION REDUCES HYPERPLASTIC GROWTH IN RENAL EPITHELIAL CELLS. Eva Bratt, Anita Aperia and Stefan $H$ Larsson. Department of Pediatrics, S:t Göran's Children's Hospttal, Karolinska Institutet, Stockholm, SWEDEN.

During postnatal maturation, the proximal tubule undergoes rapid growth, Initially mainly hyperplastic, later hypertrophic. The mechanism behind the reduction of hyperplastic growth is unknown. Proliferation was studied in proximal tubule cells (PTC) from infant (I) and adolescent (A) rats after 2 days in primary culture and analyzed by $3 \mathrm{H}$ thymidine autoradiography. The rate of proliferation was determined as the percentage labelled nuclei (ㄴ)

The cells grew in colonies with contact inhibited central cells and rapidly growing peripheral cells. The growth rate was determined in each layer of cells from periphery (layer 1 ) to center (layers $5-6)$. In layer 11 and $A$ cells proliterate at the same rate $\langle 44 \pm 4 \%$ vs $41 \pm 4 \%$ NS). Moving into the center proliferation in A cells fell faster than in 1 cells. Compared to layer 1 , proliferation in layers $5-6$ was inhlblted by $87 \pm 4 \%$ in $A$ cells whereas in I cells by $59 \pm 5 \%(p<0.05)$

To investigate possible mechanisms explaining the low degree of contact inhibition in I cells, we tested their sensitivity to growth factors. Removing serum from the culture medium lead to a more marked inhibition of I than $A$ central cells $(84 \pm 5 \%$ v8 $54 \pm 5 \%$ $\mathrm{p}<0.05)$. TGFB1 $(0.1 \mathrm{pM})$, a well characterized inhibitor of epithelial growth, inhibited I central cells by $66 \pm 7 \%$ whereas no significant effect was seen in A cells.

Conclusion: An increasing contact inhibition in rat PTC may explain the postnatal reduction in hyperplastic growth. A reduced sensitivity to growth stimulatory factors rather than an increased sensitivity to growth inhibitors is suggested.

\section{3}

CORREIATION BETWEEN BRATN NATRTURETIC PEPTIDE AND ATRIAI NATRIURETIC PEPIIDE IEVEIS IN NEONATAL PLASMA. Patricia Hamilton, Krys Matyka, Phomphimol Littleton and Nick Carter. Department
Child Health, St George's Hospital Medical School, London, UK.

Brain natriuretic peptide (BNP), first discovered in porcine brain, is principally procuced by the heart. Unlike atrial natriuretic peptide (ANP), BNP is largely derived from the ventricles. In adults plasma BNP levels, like ANP, respond to changes in blood volume and levels of 3.4-9.0 pg/ml have been are not aware of further reports on BNP in neonates.

we a do measure BNP and ANP levels in plasma from neonates with respiratory distress syndrome before and after treatment with exogenous distress syndrome before and after treatment with exogenous respective assays is $<0.0018$.

respectiv:

Individual ANP and BNP levels were compared in 41 paired samples from babies aged 4 to 80 hours. ANP levels ranged from 87-2587 $\mathrm{pg} / \mathrm{ml}$ and BNP levels ranged from $29-445 \mathrm{pg} / \mathrm{ml}$. There was a strong correlation between the concentrations of the

Conclusions:

We conclude that levels of BNP in the neonate are mach higher than reported in adults and are highly correlated with ANP, although further work is needed to establish its physiological role.

\section{4}

$\mathrm{Na}^{+}, \mathrm{K}^{+}$-ATPase IS REGULATED BY GLUCOCORTICOIDS IN AN AGE AND TISSUE DEPENDENT MANNER. Zheng-Ming Wang, Anita Aperia \& Gianni Celsi. Karolinska Institutet, St. Göran's Children's Hospital, Stockholm, Sweden. The adaptation of newborn mammals to extrauterine life is conditioned by increased expression of enzymes that are of importance for specialized tissue function. In the rat, maturation is accelerated around birth in the lung and around weaning in the kidney. The $\mathrm{Na}^{+}, \mathrm{K}^{+}$-ATPase enzyme is responsible for the active transport of ions across the membrane of each cell at the expense of $30 \%$ of total body $\mathrm{O}_{2}$ consumption. We have reported that in the infant rat renal cortex, glucocorticoids $(\mathrm{GC})$ rapidly increases the abundance of the $\mathrm{Na}^{+}, \mathrm{K}^{+}-\mathrm{ATPa}$ ( mRNA, suggesting a direct transcriptional regulation. We have now compared the effect of a single injection of betamethasone, a synthetic highly specific $\mathrm{GC}$, on the abundance of mRNA for the catalytic $\alpha$ and the regulatory $\beta$ subunits in lung and kidney from fetal, infant and young rats. In the kidney the most prominent effects on the $\alpha$ mRNA was found at 10 days of age ( $5.3 \pm 0.9$ fold). A significant increase was also found in 20 -day-old rats $(1.6 \pm 0.2$ fold) but no effect was found in fetal and 5-day-old rats. In the lung the most prominent effect was found around birth, but no effect on $\alpha$ mRNA was found at 10 and 20 days In the kidney there was a coordinate increase in $\alpha$ and $\beta$ mRNA subunits, while in the lung, the $\beta$ subunit was stimulated alone, in 10 - and 20 -day-old rats.

Conclusion. GC induction of $\mathrm{Na}^{+}, \mathrm{K}^{+}-\mathrm{ATPase}$ genes is age- and tissue dependent. The $\mathrm{GC}$ sensitive period coincides with the physiological need for organ maturation. 